\title{
Black entrepreneurs, local embeddedness and regional economic development in Northern Namibia
}

Published in Journal of Modern African Studies, 41, 4 (2003), pp. 555-586.

Hege Merete Knutsen

University of Oslo

h.m.knutsen@sgeo.uio.no

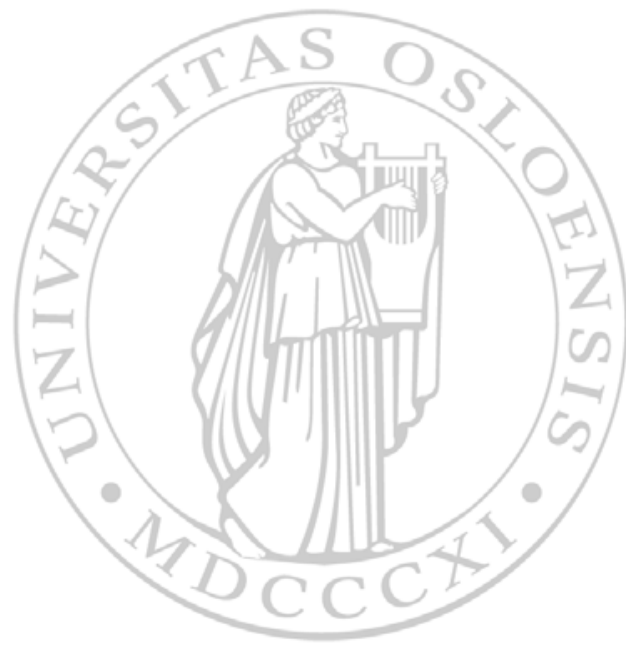

Department of Sociology \& Human Geography University of Oslo

P. O. Box 1096 Blindern

N-0317 OSLO Norway

Telephone: $\quad+4722855257$

Fax: $\quad+4722855253$

Internet: http://www.iss.uio.no/ 


\title{
Black entrepreneurs, local embeddedness and regional economic development in Northern Namibia
}

\author{
Hege M. Knutsen*
}

\section{A B S T R A C T}

The article addresses possibilities and barriers to economic activity and development in the Oshana region of Northern Namibia. The focus is on the role of local embeddedness of economic activities in attaining economic development. A network perspective, based on theories of value chains that are embedded both in social relations and spatially, is selected as the analytical framework. The value chains of local black entrepreneurs in the study area are short. Moreover, the analysis reveals that social obligations may impede economic development, but that such practices are diminishing. The economic dominance and competition from South Africa is the main impediment to economic development in Northern Namibia. Local political embeddedness is shallow and political measures have not significantly reduced the implications of this dominance.

\section{N T R O D U C T I O N}

The article addresses possibilities and barriers to economic activity and development in the Oshana region of Northern Namibia, focusing on the role of local embeddedness of economic activities in attaining economic development. Northern Namibia, formerly Ovamboland, consists of the four regions of Ohangwena, Omusati, Oshana and Oshikoto. Oshana was selected because the administrative and commercial centres of the North, Oshakati, Ongwediva and Ondangwa, are located there. The concept local refers to the geographical area of Oshana and its hinterland.

\footnotetext{
* Senior lecturer in Human Geography, Department of Sociology and Human Geography, University of Oslo, Norway.

This article forms part of a project carried out together with Sylvi Endresen, whom I thank for inspiring discussions and comments. I am also grateful for valuable input and support from Herbert Jauch at the Labour Resource and Research Institute (LaRRI) in Windhoek, and for funding of fieldwork provided by the Nordic Africa Institute in Uppsala.
} 
A study of possibilities and barriers to economic activity is warranted for many reasons. The population of Northern Namibia numbers 622,000, or $45 \%$ of all Namibia (MTI 1998). The population of the Oshana region exceeds I90,000 and is projected to reach 222,800 by 2005 (NDC n.d.). Most of the population is poor in income and material well-being, but while the population struggles to earn a decent income, economic activities flourish in the commercial centres.

Domestic and foreign capital, mostly with headquarters in Windhoek and South Africa respectively, is increasingly aware of the business potential in the North. Pilot interviews in November 1998 revealed that foreign capital had discovered the local black success stories and was outcompeting formerly successful black enterprises. Likewise, the Regional Development Plan of the Oshana region 2001/2-2005/6 states that: 'local business people are faced with increased competition from large Namibian and South African companies expanding their operations to the North of Namibia' (NDC n.d.: I27). The investments of the new entrants are mainly in trade and services, and there is little manufacturing in the region. According to a recent study (LaRRI 200I), South African, Lebanese and Iranian businesses now own most of the warehouses. In addition, South African chain stores have established a number of retail outlets, and firms from China and Botswana dump cheaper goods on the Angola-Namibian border.

Kennedy (1988: 49) argues that a vigorous local capitalist class should be promoted in Africa:

Individual foreign companies can never have the same degree of long-term interest in the attainment of higher levels of national development as local business groups, since they and their families can anticipate fewer direct or permanent benefits from such advances in the future ... overseas firms cannot be expected to respond particularly well or gladly to calls for sacrifice and change in the pursuit of national rather than purely personal goals.

His argument leads to the proposition that the economic activities of the local black entrepreneurs are more locally embedded and thereby contribute more to local economic development than domestic and foreign capital. This is examined in this paper. A discussion of the contribution of local black entrepreneurs to local economic development requires comparison with the contribution of domestic and foreign enterprises in the area. It is also necessary to look into how the more successful black entrepreneurs tackle the challenge of competition with domestic and foreign enterprises, compared with the less successful ones. Foreign capital may be more competitive but less spatially embedded than local black capital. If foreign capital transfers surpluses out of the study area, local economic 
development has little to gain from it. However, if the more spatially embedded local black capital is not competitive, this also limits possibilities for economic development.

The concept of black entrepreneurs is based on Kennedy (I988: II4-5):

they have become differentiated from petty production in the following ways: they are enumerated in government statistics; employ at least a few permanent paid workers in addition to kinsmen and apprentices; the enterprise is conducted in a legally recognised building-cum-workshop and involves some plant and equipment, however meagre; there exists an elementary form of full-time organisation (the proprietor is not normally directly involved in production); the business is no longer dependent solely on individual clients, but a proportion of output is sold to other properly constituted enterprises; and the proprietor strives, not always very successfully, to reinvest some of the firm's profits in the pursuit of business expansion.

Black entrepreneurs are involved in a wide range of economic activities and belong to the formal sector of the economy. The big black entrepreneurs in the study area are involved mainly in warehousing and building supplies, whereas the medium and smaller ones are involved in activities such as production of furniture and coffins, panel beating, and retail. ${ }^{1}$ Both big and small entrepreneurs are involved in production and sales of liquor. This is in line with the findings of Pendleton et al. (I993), that the most frequently occurring businesses in the Oshakati-Ondangwa nexus are general stores, supermarkets and bottle stores. It is also in line with Kadhikwa et al. (1996) that the most commonly found small enterprises in Oshakati and Ondangwa are furniture manufacturers, panel beaters, spray painters and metal workers. They also mention radio repairers, shoe makers, tailors and welders.

Economic development refers to a process of economic growth and structural change leading to a diversified and well-proportioned economy, where linkages between economic activities ensure that the process is sustained (Senghaas I985). The qualitative contents of economic development are higher savings and investment in employment-generating activities (Seers 1972). Employment is important as a means to attain demand-induced economic growth. Hence, one may also include increasing material welfare of the bulk of the population in the study area as a dimension of economic development. ${ }^{2}$

Some manufacturing is required to attain a well-proportioned economy, and manufacturing is given attention in the analysis due to its potential for increasing value-added and economic linkage effects. The study area is a latecomer to economic development, and one cannot expect to find the more advanced and value-generating service activities there. However, 
relatively simple manufacturing activities may become a stepping stone for more advanced manufacturing and services. Within the manufacturing sector, the goal is to advance from lower to higher quality activities (Reinert \& Riiser I994). The latter denotes products for which customers are prepared to pay higher prices. High quality activities are conducive to local economic development when they result in higher wages for the workers and thereby increase demand for products manufactured locally.

After the introduction follows a presentation of the analytical framework and research strategy. A note on the context of competition in Namibia is followed by an overview of the nature of competition in the study area. Then the economic activities are analysed in light of their functional, political, cultural, social and spatial embeddedness in the local economy. The findings are in turn examined in light of secondary contextual data in order to assess prospects for manufacturing and economic development in the region. The main findings are summarised in the conclusion, together with remarks on the usefulness of the analytical framework.

\section{A N A L Y T I C A L F R A M E W O R K}

\section{The study objects}

The study objects are the value chains and networks of selected local black entrepreneurs; domestic capital represented by entrepreneurs from central and southern Namibia and enterprises with headquarters in Windhoek; and foreign capital represented by selected chain stores from South Africa. The point of departure of the analysis is that all economic activities are embedded in networks that in turn are spatially embedded (Dicken et al. 1994). Economic activities are part of an input-output structure ${ }^{3}$ or value chain that stretches over a geographical area. How much of the value chain and what specific economic activities will be located in a given geographical area, depend on power relations (below) in the networks of which the economic activities form part (Gereffi i996). Social relations between actors, i.e. 'a regular set of contacts or similar social connections among individuals or groups' (Swedberg \& Granovetter I992: 9) turn the value chain into a network. In the following, the concept of economic networks refers to value chains that are embedded in social, political and cultural networks.

\section{The embeddedness argument}

The embeddedness argument used here has its roots in Granovetter's $(\mathrm{I} 985, \mathrm{I} 992 \mathrm{a}, \mathrm{b})$ criticism of the transaction costs approach in neo-classical 
and new institutional economics. The transaction costs approach focuses on why firms either organise production internally, purchase components and inputs in the open market, or engage in network relationships, i.e. subcontracting between different firms. The respective forms of organisation reflect different ways of dealing with the cost of economic transactions. Accordingly, subcontracting in network relationships is considered intermediate between internal organisation and market orientation. Granovetter (I992a, b), on the contrary, holds that subcontracting is not an empirical intermediate between internal organisation of firms and pure market relations. He argues that this is because pure market relations are rare, and personal relations are important in all types of organisation. One should analyse 'how behaviour is embedded in concrete, ongoing systems of social relations' (Granovetter I992b: 9, emphasis added). This does not mean that economic arguments are excluded from the analysis, but that one must move beyond economic conditions in explaining industrial organisation. The point is that: 'in identical economic and technical conditions, outcomes may differ dramatically if social structures are different' (Granovetter 1992b: 9).

\section{The extended concept of networks}

The concept of networks applied in the analysis entails more than relations between single cooperating firms. Taylor (I994: I02) defines an enterprise in a network as 'one point in a social economic constellation of points comprising other enterprises and agents'. Likewise, Gipouloux (2000) distinguishes between four elements needed to make a network work: (i) actors, both individuals and organisations, including institutions such as government agencies and universities; (ii) activities; (iii) the core resource that is exchanged (basically information and technology); and (iv) the binding mechanism. Various types of business agreements and equity shares are mentioned as examples of binding mechanisms, but in line with Granovetter (1992a) it is necessary to include social obligations and trust. Trust may replace business contracts in economic networks.

According to Taylor (1994), the actors in a network are business organisations (including enterprises), regulatory institutions and individuals. Interaction between some business enterprises is characterised by selling and buying, an interaction referred to as complementary, although it is stressed that it is unequal from the point of view of power relations. With other agents in the network, interaction is competitive or controlling. There is no direct transaction between competing enterprises, but they are indirectly affected by each other through their transactions with other agents 
in the network. Governments and unions are examples of controlling institutions.

The concept of network applied in the analysis implies that the analytical focus is extended from economic activities per se to the character and extent of any social relations that are relevant to the actors' economic activities. Transactions that take place in the networks are manifestations of social relations. ${ }^{4}$ At the level of personal contacts, social relations give access to resources to set up and run an enterprise. Contacts include suppliers, customers, banks and finance institutions, business experts, industrial associations (private) and industrial departments (governmental), family and friends. Moreover, the entrepreneur may be involved in social relations that result in the channelling of resources out of the value chain in question and into another, for example when consumption takes place to the detriment of reinvestment.

\section{Social, political and cultural embeddedness}

Zukin \& DiMaggio (1990), who have further developed the embeddedness argument, distinguish between cognitive, social, political and cultural embeddedness. For practical reasons, the issue of cognitive embeddedness ${ }^{5}$ is not addressed in this study. Social embeddedness refers to the nature of interpersonal relations, and social networks are understood as personal contacts between managers, and between these and other actors who are important to the performance of the economic activity (see Isaksen I994). Trust is the glue in these relationships and is understood as 'confidence in the continuation of a mutually satisfying relationship' (Wu Wei-ping 2000: 45).

Cultural embeddedness refers to how collective understanding shapes economic strategies and goals, and sets limits to economic rationality. Cultural networks comprise relations between the enterprises and the wider community in which their economic activities are carried out. Common culture and values in locations where the economic activities take place are an important source of trust, and also a basis for personal contacts and favourable political relations (see Isaksen i994).

Political embeddedness refers to 'the manner in which economic institutions and decisions are shaped by a struggle for power that involves economic actors and non-market institutions, particularly the state and social classes' (Zukin \& DiMaggio 1990: 20). A case in point is how governmental policies, laws and regulations affect the structure of the market. Political networks refer to relations to the political elite and regulatory authorities. The example of bank credit illustrates the difference between 
social and political embeddedness. If the entrepreneur obtains credit due to wealthy friends or relatives who provide collateral, or because he is on good terms with the bank manager, this is an example of social embeddedness. The same is the case if individuals get bank loans due to personal political connections. However, if a black entrepreneur obtains credit due to a government programme to stimulate economic initiatives among the black population, this is an example of political embeddedness.

\section{Functional and spatial embeddedness}

Spatial embeddedness has two dimensions (Dicken et al. 1994). The first simply means that the economic activity contains something local, just because it has a specific geographical location. It refers to how much of the value chain, i.e. input-output activity, is located in the study area, and thus to what degree the activity is functionally embedded in the area. The other dimension is deeper because it takes into account that the economic activities are embedded in social, political and cultural networks. Activities that are functionally embedded in the study area may to a limited extent be socially, politically and culturally embedded in that area. The character of local networks is influenced by relations the actors may have elsewhere. Moreover, the nature of networks in the local setting is influenced by socio-economic processes at the global level. Some networks may actually be more global than local in orientation. This link between the local and the global has direct relevance for power relations at the local level.

\section{Power relations}

Granovetter (I992a) emphasises that power relations in terms of domination and subordination cannot be neglected in studies of industrial organisation; complexities arise even when formally equal parties negotiate, and many of these are resolved by implicit and explicit power relations among firms. Taylor (1994) and Taylor et al. (1995) incorporate space and place in their power networks approach. ${ }^{6}$ They build on Clegg (I989), who distinguishes between three non-hierarchical interacting circuits of power. The power circuits capture the dynamics of the networks, i.e. how and why power relations in the network change.

The first circuit of power is the circuit of causal power where agency is the analytical level. Power is based on money and authority and only exercised episodically. It focuses on the time-specific and place-specific relations between business enterprises, individuals, institutions and governments. The reason why power is only exercised episodically is that it is in 
the interest of all parties to minimise network disruption and uncertainty, so as to protect production, consumption and investment.

The second circuit is the circuit of dispositional power. Here power is dealt with at the analytical level of social integration and the focus is on rules of practice. This is where rules are fixed and compulsory passage points to become members of networks are established. The rules and passage points are time and place specific, and reflect accepted norms of local societies. Dispositional power is a means to cement existing power relations. However, agencies may attain power when episodic spells of pressure and resistance in the first circuit result in changes in the rules and passage points of the second circuit. The place-specific rules and passage points may also be modified and changed due to changes in regulations at the domestic and international levels.

The third circuit is the circuit of facilitative power at the analytical level of system integration. The focus is on domination. The facilitative circuit represents an opening for new agents to gain power and become dominant in the network. This is because innovation in techniques of discipline (for example, control of labour) and production will empower some agents and disempower others. Such innovations can occur locally or be a result of exogenous forces. It is important to note that rules fixed in the dispositional circuit can both facilitate and restrict such innovations. However, when such innovations occur, they affect rule fixing and passage points in the dispositional circuit and standing conditions in the causal circuit. This power networks approach will be applied in the analysis because it distinguishes between different spatial levels of analysis, and elucidates how the local and global are interlinked.

In sum, the nature of networks, in terms of power relations, collaboration and competition, is essential to increasing and sustaining local economic linkages and the multiplier effects of economic activities. Moreover, activities performed in the local economy may be more functionally, socially, politically and culturally embedded in other geographical areas than the study area. If so, the network has an outward orientation and local embeddedness is shallow. In the Namibian case, local black capital, domestic capital and foreign capital may all be more embedded in other networks than the local, but to a varying degree. Spatial embeddedness - the nature and degree of local embeddedness - is a cross-cutting issue in the analysis.

RESEARCH STRATEGY

The research strategy adopted is a theoretically informed and qualitative case study. The primary data was collected in Oshakati, Ongwediva and 
Ondangwa in November 200I. Two key interviews on the general competitive situation were conducted at the Namibia Chamber of Commerce and Industry (NCGI), Northern Branch, one being a focused group interview with three members and the business advisor. A manager in the local branch of one of the big banks was also interviewed. As a starting point, official lists of businesses in operation were obtained from the Northern Electricity Board. ${ }^{7}$ Ideas about whom it would be useful to meet in order to cover the various aspects of our research questions were obtained from resource persons in the North and in Windhoek. Interviews were then carried out with nineteen local black entrepreneurs and ten investors from outside, i.e. chain stores and entrepreneurs with large, medium and small enterprises, although not micro-enterprises. The local entrepreneurs represented different types of economic activities, such as auto repairs and sales of petrol; building construction; retail in building materials and auto parts; printing; sewing; woodwork; funeral services; wholesale and retail grocers; liquor stores and supermarkets. A number of the entrepreneurs were involved in more than one activity. The sample encompasses both successful entrepreneurs and those who struggle to survive, including some who are still trying to keep going, some who have diverted into other activities while retaining the initial activity, and others who have closed down the initial activity and shifted to new ones. Whether entrepreneurs in the two latter categories become successful in the longer run remains to be seen.

THE CONTEXT OF GOMPETITION IN NAMIBIA

From I9I5 to 1990, Namibia was a South African colony. The relationship was characterised by a classical division of labour, in which South Africa extracted raw materials from Namibia, and Namibia served as a protected market for South African manufactures. Northern Namibia was a source of migrant labour. In the I950s, 'two or three' local Africans got licences to run shops taken over from Europeans (Mbuende 1986: 193).

As a result of internal and international pressure after Angolan independence in 1975, South Africa shifted from a bantustan (homelands) policy $^{8}$ to a policy of internal settlement. The bantustan policy implied that a homeland was established for each population group. Whereas the white homeland covered the mineral-rich central plateau and was incorporated into South Africa, none of the black homelands were economically viable. An objective of the internal settlement policy was to promote a collaborative African bureaucracy and petty bourgeoisie, and in the late I970s more local black entrepreneurs were permitted to set up businesses 
in the North. However, the federal model of government ensured that de facto power lay at the level of the bantustan governments. Hence, African migrant workers could not participate in decision-making in the white area. There were 'comparatively few changes to the underlying political economy or relations of production' (Simon $1985: 508$ ), and the internal settlement strategy was criticised as no more than a sophistication of the homeland strategy (Jauch I998; Mbuende I986).

In the I970s and until the late I980s, demand for consumer goods in the North was high, due to the presence of the South African army and a large number of white inhabitants. During the struggle for liberation, South African companies were reluctant to settle down in the North. This changed with independence in I990. The influx of South African companies increased throughout the ig9os, stimulated by the open economy and free trade policy pursued by the Namibian government.

Due to the South African colonial policy, manufacturing accounted for only $5 \%$ of GDP at the time of independence in 1990 (Curry \& Stoneman I993; UNIDO I990). By I998 it had increased to I2 \% (UNIDO n.d.). The government of Namibia rides many horses in its industrial policy (Endresen \& Jauch 200I). Official documents reveal that government policy is both to promote free trade in order to attract foreign investors, and to promote selected industrial sectors with a comparative advantage in exports. In addition, there is a policy to stimulate smaller-scale Namibian businesses. The Foreign Investment Act of 1990 provides for non-discrimination between local and foreign investors (UNIDO r994), ${ }^{9}$ but stated aims of the 1992 White Paper on industrial development are both to 'increase manufacturing value-added by stimulating productivity, increased exports and where efficient, import substitution', and to 'increase the participation of Namibian citizens previously excluded from industrial activities by giving preferential access to lines of business favouring small-scale activities' (ibid.: 21).

In 1995 the Export Processing Zone (EPZ) Act was passed. In I997 the government promised assistance to small and medium enterprises (SMEs) because such enterprises are important job creators, and stated that exportled growth was the only viable strategy for sustainable economic development and massive job creation (Republic of Namibia 1997). A document on industrial policy beyond 2000 (MTI 1999) emphasised - in line with a neoliberal approach - that free trade and trade liberalisation were important for industrial development, and that intervention should operate through the market by incentives and information.

The economic strength of South Africa in southern Africa represents a structural constraint to production in Namibia. In the international 
context, the market in Namibia in general (and Northern Namibia in particular) is small, and purchasing power is low. Products are imported from South Africa, where they are manufactured for a bigger southern African market. As a member of the Southern African Customs Union (SACU), Namibia cannot protect its industry from South African imports, while imports from countries outside SACU are subject to high tariffs. South Africa is by far the strongest party in SACU. Not only does South African industry benefit from economies of scale and technological superiority vis-à-vis Namibia, but firms in nine economic regions in South Africa are actually subsidised by the Regional Industrial Development Programme. On top of this, the monopoly situation enables South African firms to further strengthen their position by dumping, over-pricing and restrictive purchasing policies in Namibia (Curry \& Stoneman 1993).

Simon (200I) documents the increase in South African outward foreign investment and trade in the I990s. Figures from I997 reveal that Namibia holds $23 \%$ of the direct and non-direct South African assets in eastern and southern Africa. This is the largest share among the countries in this region. According to the study, South African companies market themselves as continental and global players with expertise, experience and resources, and African host countries tend to welcome South African trade and investment in order to secure employment and promote production. The products are cheap and considered appropriate for the local markets.

COMPETITION IN THE NORTH

The fact that it became easier for local black entrepreneurs to set up businesses in the late I970s and I980s, and the protection from which they benefited, represented a change in the circuit of facilitative power. Protection was not part of an economic policy, but an outcome of the struggle for liberation. A new change in the circuit of facilitative power took place in the Ig9os with the introduction of the free trade policy. How this affects local black businesses and their power in business relations is addressed in the following.

The investors in the North are mainly big South African chain stores, which sell groceries, textiles, garments, electrical consumer goods and furniture, and cater predominantly to the middle-class market. They have a number of outlets in Namibia and all over Southern Africa. They buy in bulk from their suppliers and thus obtain economies of scale that enable them to compete fiercely in price cutting, provide a wide range of quality goods, and retain a comparatively high level of wages for their workers at the same time. Local big black entrepreneurs cannot negotiate the same 
low level of prices with their South African suppliers (interview). During the colonial time, South African firms were known to undercut prices to prevent local firms starting production (Sparks \& Green I992). The practice is still pursued. This can be illustrated by the example of three businessmen from South Africa who said that they were in the North to identify successful local undertakings, set up similar businesses, and outcompete the local ones on price (conversation November 1998). Big companies, like the South African ones, have sufficient resources to run at a loss for a certain period in order to ensure large market shares and high profits in the longer run.

It is particularly in groceries and supermarkets that some of the local black entrepreneurs struggle. Profit margins are about 7-8\% in wholesale and $23 \%$ in supermarkets (interview). One local black entrepreneur explained that he did very well in the I980s, but had to close down in I990. Instead of retail, he now rents out his shop building and has built a block of flats for rent. Another entrepreneur in the sample also plans to build flats for rent as a means to diversify. Flats in the area are rented out for 300-350 Namibian dollars (NAD) a month. ${ }^{10}$ It is difficult to obtain a higher price, and this is not considered a good return on investment according to a respondent in the housing sector. When it comes to clothing, chain stores that market fashion goods are popular with the young black population, but local black tailors who make both Western and African fashion clothes are also successful. The data suggests that the biggest challenge for the local black entrepreneurs is not the ability to supply the market with modern products that are in demand, but to do so at a competitive price.

Small and medium-scale entrepreneurs from central and southern Namibia engage in activities such as subcontracting in building construction and auto repairs. According to a white entrepreneur, the construction industry is booming and there is sufficient work for all. The expertise of big foreign companies is required in multimillion projects, but it is difficult for local black entrepreneurs to make a success as subcontractors in building construction, because this requires a lot of starting and operating capital. The problem is reinforced by difficulties in getting bank loans and the high interest rates on such loans (below). These entrepreneurs have outlays on equipment and material, and are only paid after a substantial part of the job has been done. One subcontractor in building construction stated that he was paid on a monthly basis, and only at a given rate per square metre completed. Hence, delays cause serious economic problems. In addition, local black entrepreneurs hold that white entrepreneurs have far better access to bank loans. 
One local black entrepreneur in auto repairs stated that there were few auto repair shops in the region just after independence. The increase in economic activities and improved salaries made it possible for more people to buy cars. The cars are insured and insurance companies encourage entrepreneurs in the South to set up businesses in the North. Insurance companies check facilities and the quality of work before they approve auto repair shops, and both black and white auto repair shops have contracts with insurance companies. However, the local black entrepreneur claims that his business is declining, while white panel beaters get plenty of jobs. This is confirmed by a white entrepreneur who gets a lot of work from insurance companies.

\section{SHALLOW FU XCTIOXAL EMBEDDEDNESS}

With reference to Kennedy (I988), one may expect local black entrepreneurs to have far more input-output linkages with the local economy than domestic and foreign enterprises. Moreover, it was expected that local black entrepreneurs would be more likely than domestic and foreign investors to cater to the poorer niches of the local economy. This should stimulate generation of local linkages and thereby local embeddedness.

The data did not support this line of argument. The production equipment and inputs used by local black entrepreneurs originate first and foremost from South Africa. This applies to all categories, including manufacturing, repairs, construction, and wholesale and retail trade. Purchases were made directly from South Africa, or bought from South Africa via affiliates in Windhoek. According to one interviewee, a retailer in auto spares, there is some tendency to avoid Namibian-based branch offices and retailers, and import directly from suppliers in South Africa. However, a white entrepreneur said that although he sometimes buys directly from South Africa, he buys most of his parts from Windhoek and the local branch of the Windhoek-based company. Because he buys a lot, he is entitled to a high rate of discount. He does not rule out purchases from 'local guys', i.e. small black entrepreneurs. They provide smaller items such as bull bars and brake drums, and $70-60 \%$ of the locally cut engines are considered to be of good quality.

In the units in the sewing sector, Namibia-based firms that sell fabrics from South African and other foreign countries are mostly avoided. In addition to direct imports from South Africa and purchases from South African sales representatives who visit the region, local black entrepreneurs buy fabrics in Thailand and the Democratic Republic of Congo (DRC). They travel abroad to establish business relations or select 
fabrics in the street markets. When they do not go through acquaintances, they contact the embassies for addresses of potential suppliers. One printing shop had recently purchased a new laser printer directly from Germany. The purchase was made on the Internet, as this was cheaper than buying it in Windhoek. Another local black entrepreneur found three of his suppliers on the Internet. More extensive use of the Internet in future may further by-pass dealers in Windhoek and Southern Africa. One manufacturer who caters to the lower end of the market prefers to buy inputs from local shops. He does not 'believe in' going to South Africa for inputs. This could be a result of both the cost of the journey and his age.

Although local black entrepreneurs have closed down some activities due to competition, new activities are started and reinvestment take place locally. White Namibian entrepreneurs who have settled down in the North also reinvest and expand their business there. In contrast, South African chain stores are known to repatriate their surpluses. It is also claimed that some of them disinvest due to the saturation of the market, which they perceive as declining purchasing power: 'they pack their suitcases, take their money and return (to South Africa)' (interview with a bank manager, parenthesis added). Technically speaking, repatriation of profits is facilitated by the Common Monetary Union (GMU), also referred to as the Rand monetary area. ${ }^{11}$ Namibia got its own currency in I993, but the South African Rand is legal tender and freely interchangeable with the Namibian dollar (Sparks \& Green I992; UNIDO 1994). South African investors in Namibia can deposit money directly into their home accounts.

The value chains formed by local black entrepreneurs were short or almost absent in the study area. In other words, the functional embeddedness of local black entrepreneurs in the local economy is shallow. In addition, there are signs that outward orientation is on the increase. This can be explained by tough competition and the need for cost cutting. However, in the sewing sector, purchase of fabric abroad is also a strategy to provide unique and fashionable products. Local black entrepreneurs are not significantly more locally embedded in terms of supplies than domestic entrepreneurs and foreign investors. Some reinvestment in the local economy is undertaken by both local black entrepreneurs and domestic entrepreneurs, while South African chain stores tend to repatriate profits. Only one of these chain stores buys some fruit and vegetables locally. The shortness of these value chains is in line with the findings of Pedersen \& McCormick (I999) that indigenous African business systems are fragmented. 
Many ruling party members come from the study area, which is strategically important to attract voters. Special emphasis and measures by the government to create employment and develop the region economically may stimulate black economic activities. Does this reflect political embeddedness which strengthens black business activities? White national capital can also be promoted by black governments for the purpose of industrialisation and capital accumulation, as in the case of Zimbabwe (Nicholas 1994; Ostergaard i994). Pedersen \& McCormick (i999) hold that declared socialist governments in Zimbabwe, Tanzania, Ethiopia and Mozambique have been reluctant to promote an indigenous business class that can compete with them for power.

Political embeddedness in the North manifests itself in the fact that a lot of public investment takes place there, such as the establishment of a branch of the University of Namibia (UNAM), establishment of a high court and expansion of the hospital. A branch of the National Reserve Bank was due to open in March 2002. A Deeds Office and the Namibia Intelligence Service were also due to be established. Oshakati is designated to become the economic capital of Northern Namibia by 2016 (Urban Dynamics 200I). The investments are made to facilitate increasing local governance in line with the decentralisation policy of the government under the Ministry of Regional and Local Government and Housing. ${ }^{12}$ According to this policy, a number of functions such as community development, primary health care, management of communal lands, and physical and economic planning will be decentralised to the regional councils of the thirteen regions of Namibia. However, public investments such as those in the North are not taking place in the other regions.

The government implements affirmative action to redress the negative effects of discrimination against blacks during the colonial period. So far, affirmative action has advanced the fastest in civil service employment. In the private sector, employers are permitted, but not compelled, to practice affirmative action (Jauch I998). ${ }^{13}$ The fact that affirmative action has created fear of reverse discrimination among white males, may represent a small push towards private sector involvement in the north where they see that economic activities flourish. According to one white respondent: 'White people move in, whereas rich blacks move to Windhoek' and 'Whites move in because they know that the government won't let the North fall to pieces.'

Government policy may favour the black population in the region, in the sense that they are the main beneficiaries of affirmative action in the 
civil sector. One white respondent claimed that the government pumps in money in order to compensate for the negative effects of the open market. However, in practice, the decentralisation policy is of no particular advantage to local black entrepreneurs who operate in the private sector. They still lose in the competition with investors and entrepreneurs from outside. Measures were taken to make it easier for the local people to get tenders in construction, but according to local business people, this did not work: 'However, other brothers (i.e. entrepreneurs from the South) realise this (that requirements to get tenders are lowered) and sprint in, and they are the investors. Standards cannot be lowered when qualified people are here' (interview, parenthesis added). His point is that entrepreneurs from the South move to the North, and then get the projects because they are better qualified.

Moreover, both black and white entrepreneurs in building construction complain about the performance guarantee of $10 \%$ of the costs that the Namibian government demands on its projects. In contrast, the South African government demands a guarantee of Io \% only on projects exceeding Io million Rand. For projects up to a value of I million Rand the latter demands only i \%. The requirement of the Namibian government makes it difficult for small local enterprises to bid for government tenders in construction. Hence, in practice such tenders do not really serve as incentives to boost local black enterprises.

Local black entrepreneurs hold that government tenders tend to go to big Namibian or South African firms. Government tenders can only be given to enterprises that are registered for value added tax (VAT) and social security. The entrepreneur has to keep accounts, which in turn requires training, time and paper work. Registration is voluntary for enterprises with a turnover of less than NAD 200,000. In order to get a government tender, the enterprise is not permitted to make use of unregistered sub-contractors. Tenders are evaluated by a board in Windhoek. The final selection is up to the relevant Ministry. The government is not legally bound to take the lowest offer. One local black entrepreneur thought that small enterprises have difficulties in getting government tenders because the government fears that they do not possess the infrastructure to deliver the goods. In one case it took a local black entrepreneur about six years to get his first tender.

There is frustration among local black entrepreneurs that measures are not taken to protect them against competition from South African investors and entrepreneurs from the South. Their argument is that competition takes place on unequal terms. In addition to the economies of scale of the South African companies, black entrepreneurs have difficulties 
in raising capital. At the entrepreneurial level, access to credit is a barrier to establish, upgrade and expand manufacturing production and other businesses. The need for credit has been a major concern of black respondents in a number of studies carried out in Namibia and other African countries (Kennedy i988; MTI ı998; Pedersen 200I; Pedersen \& McCormick I999). Banks are reluctant to give loans to black entrepreneurs and interest rates are high. One big difficulty when starting a business is to provide the required security to obtain loans. Kennedy (I988) also points to the need to learn how to apply for loans and be able to document expenditure, income and assets properly. Over time a number of special credit schemes directed at small enterprises have been launched by the government, which provides security in the current credit scheme. Applicants are required to submit a business plan and sit for an interview. The local black entrepreneurs complain that it is extremely difficult to get such loans and that they are not informed why their applications are rejected. One bank manager argued, for his part, that many projects are economically unviable and that this is partly due to bad advice from business advisors: 'The people who make the business plans for the entrepreneurs rip them off. Those who make business plans should be experts.' Moreover, he claims that entrepreneurs can ask for an appointment to know in more detail why their applications were rejected. However, it is not common to do this, and entrepreneurs do not know how to proceed after a rejection. Savings are not always sufficient for viable investments and entrepreneurs also need operating capital.

When security is required, the banks ask for savings and title deeds. It does not help to have a shop or a nice house as long as you do not have title deeds to the land. This reflects contradictions between the traditional and the new system of land ownership. Previously traditional leaders sold permission to occupy land (PTOs) and persons with such land did not usually have papers to this effect. They are of the opinion that the land is theirs because they have paid for it, but such land is not accepted as security by the banks. When Oshakati, Ongwediva and Ondangwaa became metropolitan areas in the late I990s, the right to the land was transferred from the government to the respective municipalities. Currently, the respective municipalities sell land for housing schemes and business undertakings, and the land values are on the increase. Some of the entrepreneurs in the sample have bought such land, but there is also frustration that one has to 'buy land twice', and that it is difficult to raise the money. From the town councils' perspective, however, income from land is an important source of revenue to provide infrastructure such as water and sanitation (Simon 1996). 
Bank savings can be used as security, but black entrepreneurs cannot borrow much more than they have already saved in the bank. The interest rate is considered high and some would rather spend their own savings, which is not uncommon among small entrepreneurs in Africa (Pedersen 200I). In Northern Namibia the banks assess the loan applications and decide the interest rate on a case-by-case basis according to the risk involved. The minimum interest rate is $14 \%$.

The data do not suggest any significant improvement in access to credit for local black entrepreneurs. In other words, political embeddedness does not matter much in terms of access to bank loans. Some local black entrepreneurs express frustration that it is always difficult for the blacks to obtain bank loans. They claim that the bankers protect white interests and cannot make decisions without the consent of the head-office in Windhoek. They also claim that local black employees in the banks only serve as window-dressing. The power resides with white managers in the South to the benefit of the whites. Having said this, the bank manager holds that the foreign chain stores bring in their own capital. Hence, they do not outcompete the local blacks regarding access to credit.

The experience of both the local black entrepreneurs and entrepreneurs and investors from outside is that the main concern of the government is the free trade policy, and that this dominates industrial policy. Some local black entrepreneurs also stressed that the government is informed about the problems of the local black entrepreneurs but does not do anything because action would not fit with the free trade policy. This is in contrast to the ambiguity expressed in the government policy documents noted above. The Namibian Chamber of Commerce and Industry (NCGI) arranges meetings with government officials and sends letters to explain the problems of local black entrepreneurs, but meetings with relevant ministers take a long time to arrange and are of little practical help. Any break with the government's free trade policy might cause insecurity and resistance among foreign investors, and its inclination is to protect the present pattern of production, consumption and investment. It is indicative of business as usual in the circuit of causal power.

This indicates that the political embeddedness of local black entrepreneurs is less than expected, and that measures which could have strengthened their businesses are of limited avail. At the macro level, opportunities inherent in the decentralisation policy are difficult to capture for the local black entrepreneurs, since they have to compete with large capital-strong companies that are competitive in both price and quality. There is also frustration about lack of information regarding industrial policy and regulations at the national and local level. The situation in 
Namibia differs from Zimbabwe, where white national capital has been actively promoted by the government. Namibia got its independence at the height of an era when free trade was advocated and promoted internationally. The problems faced by local black entrepreneurs thus largely derive from lack of protection in competition with new entrants, especially from abroad, who have much greater financial and technological resources.

G ULT UR A L EM B E D D E D N S S: F A G I L T A T O R A D I M P E D IM E T

As noted above, cultural embeddedness refers to how collective understanding shapes economic strategies and goals. On the one hand, culture may set limits to economic rationality. On the other hand, common culture and understanding of common values in the location where the economic activities take place, are an important source of trust which in turn can be important to obtain economic success.

The traditional system of inheritance is not conducive to economic development in the longer run. As some local black entrepreneurs said: 'When a business person dies, the enterprise dies with him as the relatives split the enterprise and share the value between them.' When the husband dies, his family and relatives inherit. The rule of descent is matrilineal and, by tradition, children do not inherit from their father, but are heirs-to-be of their maternal uncle (Malan i995). After independence people could choose between the traditional system and modern law. In the latter case, they make a will or register as a share company. Wills and shareholding have become more popular as education has improved.

Some local black entrepreneurs had concrete plans to establish share companies, not only as a matter of inheritance, but to boost business. Their objectives were to expand the capital base, make management more permissive, and increase the knowledge base:

Failure in industry is often a result of poor management. One can overcome this by forming a group of people with different ideas and common goals. One has to learn from other people's experience. To get government tenders one has to be big. It is a matter of raising capital ... [and] we are stronger when united [local black entrepreneur].

An obligation to employ family members in key positions, irrespective of background and skills, may undermine the growth and development of the enterprise (Kennedy I988). This indicates a situation where cultural and social embeddedness are in conflict with economic development. Interestingly, the findings suggest that attitudes and practice regarding such social obligations are about to change. 
In the interviews it was agreed that pressure to employ family members and relatives exists. Many of the local black entrepreneurs in the sample still employ family or relatives. They have different experiences with it, but it is not considered a significant problem. According to one local black entrepreneur: 'If you earn more than NAD Iоoo a month, it is your obligation to look after family members and relatives.' Others also held that it is common to look to 'the stronger person in the family' for help. However, with improved education, people can maintain themselves and social obligations mean less: 'Social obligations are not a main problem now.' 'You can give them easy jobs such as cleaning.'

Those who were in favour of family labour argued that they are loyal and do not steal, and that they need a loyal person to take care of the business when they are away. Their experiences were positive. Those who argued against, had negative experiences. One local black entrepreneur looked at it this way: 'Family members don't steal, but won't work either.' He had previously employed family labour, but had dismissed them. Yet another entrepreneur held that family labour is not successful, they both steal and do not work. One black former panel beater from the South who had recently moved to the North said that he did so in order to escape friends and customers who never paid him, and because he did not like to spend so much on family and relatives.

There was agreement among local black entrepreneurs that family obligations do not prevent reinvestment. 'It is not correct that they only spend money on family. That was the previous generation' (old local black entrepreneur). 'People are prepared to reinvest and do their business, but unfortunately some businesses are unviable and go bankrupt' (local black entrepreneur). In one case it was mentioned that one must plough back $60 \%$ of the earnings and not take out more than $40 \%$ for the family. Most of the businesses have expanded little by little by savings and reinvestment, including upgrading and renewal of equipment and expansion. Some purchase land and invest in buildings for their businesses. A few cannot afford any of this, and only have operating capital to keep the business going. One local black entrepreneur considered the enterprise as a way of life, and subsidised it when necessary with inherited money and income from other sources.

Some divert into new activities when they experience fierce competition. Investment in commercial farming is a case in point. It was sometimes mentioned that 'big locals shift to commercial farming' and that 'it is a new phenomenon to take out money and invest in commercial farming'. Commercial farming, with the exception of a few projects in the North, takes place in central and southern Namibia. A couple of respondents 
mentioned that their dream was to invest in a commercial farm where they could stay when they retired. Only three of the local black entrepreneurs in the sample were involved in commercial farming. One of them experienced severe competition in wholesale and retail, but had taken up commercial farming before the downturn. He stressed that 'a farm is more important to a man than a shop'. He was also concerned that family and relatives can stay at the farm. Traditionally, Ovambo men practised cattle herding, and women food collection and cultivation for subsistence. The agricultural sector, hunting and forestry absorb about $40 \%$ of the economically active population in Oshana, but still mainly at the subsistence level (NDC n.d.). Although there are elements of cultural embeddedness in the present interest in a 'return' or withdrawal to farming, ${ }^{14}$ the fact that agriculture has remained a dominant activity for so long is also an economic necessity resulting from apartheid and the political economy of the country.

To the extent that competition from outside investors stimulates a shift to commercial farming, this also stimulates the flow of money out of the area, to the possible detriment of local economic development. Because few other investment opportunities are attractive to local black entrepreneurs in the North, income from commercial farming will at best be channelled back into some demand in the retail sector that South African investors dominate. This implies that the surplus trickles out of the North and out of Namibia. In order for cattle and goat farming to serve as viable commercial activities and as a source of value-added in the North, a number of barriers have to be dealt with, including removal of the veterinary cordon fence and improved veterinary services and improved marketing (NDG n.d.).

Having discussed forms of cultural embeddedness acting as barriers to economic development, the next question is how cultural embeddedness may enhance local business through common understanding and trust. Relations with the neighbouring countries, Angola and DRC, show how political, cultural and social embeddedness are intertwined. The cultural link to Angola is the stronger of the two, as the traditional land of the Ovambo stretches into the Cunene district of southern Angola, and Angola supported SWAPO in the struggle for independence in Namibia. More recently, Namibia sent troops to Congo when President Kabila was under military threat.

The Namibian government has targeted Angola as a main trade partner (Sparks \& Green 1992). Residents and refugees from Angola travel to northern Namibia and add to the local market. Angolans are popular customers because they buy in bulk and pay cash in US dollars. At the moment their major demand is for building materials. According to a 
respondent in wholesale and groceries, they also come for beer, cold drinks and whisky, but tend to buy foodstuffs in bulk from South Africa. However, Angolans are buying less than before, and - like local black entrepreneurs in Namibia - increasingly cut out the middlemen and deal directly with factories in South Africa. To set up a business in Angola was generally considered risky at the time of the war between the government forces and insurgents. Two of the black entrepreneurs had to close down their affiliates in the Namibian border town of Oshikongo, due to the unrest and robbery. At the time of the fieldwork, a delegation of Namibian entrepreneurs planned a business trip to Angola to explore investment opportunities. It is especially in respect of building contracts that they find Angola interesting: 'There are risks involved and a lot of money to be earned, but there are also some relatively safe places' (interview). An advantage is that building construction in Angola can be managed from Namibia.

According to one local black entrepreneur, the government wants to promote business collaboration and trade between Namibia and DRC, but does not want entrepreneurs 'to go and exploit their brothers in Congo'. High prices can be obtained in DRG due to scarcity of numerous goods. Only a few of the local black entrepreneurs in the sample go to DRC on business trips, either in order to buy inputs or to plan for exports. This interaction is based on acquaintances.

In historical perspective, the cultural and political embeddedness manifested in the fight against apartheid form the core of the relations with Angola and DRC. This has given rise to personal relations, which facilitate interaction today. Those who trade with Angola and DRC belong to the more successful local black entrepreneurs in the sample. In addition, local black entrepreneurs, domestic entrepreneurs and chain stores in the North benefit from Angolan demand in Namibia. The two neighbouring countries provide markets for those who are already successful in their businesses, rather that those who are squeezed out of the home market.

Angolan and Congolese customers may boost the business of local black entrepreneurs in the short term, and probably longer in some niches of the sewing sector, where the uniqueness of the product is essential, and it is easier to establish personal relations with customers. However, a local black entrepreneur who tried to establish a manufacturing unit ${ }^{15}$ in the North based on technology from DRC, found that the company he approached in DRG wanted instead to export to Namibia, although it would be cheaper to manufacture the product in Namibia, and suggested that the local black entrepreneur be their sales agent. DRG policy is to promote South African investment in key areas such as mining, construction, telecoms, agriculture and agro-processing, energy and tourism. 
South African investors are attractive because they have money and skills, as well as 'the innate understanding of the prevailing conditions on this continent' (Traders 200I: 17); they are involved in similar businesses in Namibia. This shows how difficult it is for Namibians in general and local black entrepreneurs in particular to rely on external demand in the longer run, when the internal industrial base is shallow. Moreover, the business elite in South Africa is white, and retains some scepticism and distrust towards blacks, which affects the opportunities open to local black entrepreneurs.

S O G I A L E M B E D D E D ES S: EXTER N L O R I E T A T I O N

Social embeddedess takes place through interpersonal relationships (Zukin \& DiMaggio I990). Good relationships with suppliers of equipment and inputs were important to all the local black entrepreneurs. It was common to have met suppliers in person, even though many had to travel all the way to South Africa to do so. Social embeddedness in respect of relationships to suppliers is to a large extent externally oriented. Personal meetings are a means to establish trust. It is easier and safer to order by fax and telephone when the parties have met each other before. Personal meetings with the suppliers in order to bargain for credit are not common. In fact, many entrepreneurs prefer to pay cash in order to get discounts.

Problems of access to information about relevant government regulations were sometimes mentioned. Personal relations with persons in the political elite are important both to get such information, and to get help to take advantage of opportunities provided by industrial policy and regulations. For example, the fact that local exporters may seek EPZ status is not commonly known.

It is clear that the largest entrepreneurs in the region have personal political connections, but concrete information about their nature and implications for economic activities was not revealed. Only one of the entrepreneurs talked about personal political connections. This did not help her to set up the business in the first place, but the status it gave provided a market opportunity for higher quality products, and members of the political elite were among her customers. The political elite spends weekends in the North and goes there for special occasions such as weddings and funerals. Other entrepreneurs expressed frustration or resignation that they did not get help from the politicians. Although personal connections with politicians may have been downplayed by the respondents, the outcome of such possible relations does not seem to have been of any significant help, given the problems that the entrepreneurs have to cope with. 
As for personal relationships between entrepreneurs, some black entrepreneurs said that they had given business advice, although not money, to fellow entrepreneurs. However, it was also claimed that 'people here are selfish' and 'they do not talk much and they do not co-operate much'. This is not surprising in the light of the recent war of independence. People who supported different sides and factions during the war may find it difficult to trust each other in business a few years later. In contrast, the case of six friends who were about to form a joint venture illustrates that it is possible to build on trust. One of them said that they 'have come a long way together', and had been friends long before they decided to cooperate in a joint venture. In another case in the sewing sector, ten small entrepreneurs who are located in the same vicinity cooperate. Eight of the ten are so small that they are not registered. One of the registered entrepreneurs assists the others with designs and cutting, and helps them to contact suppliers she has confidence in, and to draw up business plans. This is important, because small entrepreneurs are reluctant to attend workshops, and prefer to be taught one by one, by a person whom they know.

Not all of the local black entrepreneurs were members of the Northern branch of NCGI. The most common argument among non-members was that they had not been directly approached by the organisation. A few mentioned that they felt they were too new in the business to join, and one argued that it would not help him very much because 'the large do not want to share ideas with the small'. The local annual trade fair that NCGI arranges for business people to meet and promote economic activity in the region was very popular, with over 350 exhibits in 200I. The Northern branch of NCCI is in practice predominantly an organisation for local black entrepreneurs. Local affiliates of firms in Windhoek are registered with the Windhoek branch of the NCCI, and do not engage in the activities of the Northern branch, even though local affiliates are supposed to register at the local branch. A few white investors belong to the Northern branch, but some black members regard this with suspicion. Some of the white investors believe that the Northern branch of NCCI is more for the smaller entrepreneurs who are in need of business training. Although rules have changed on paper, changes in practice take time. Scepticism is due to the history of apartheid and the dominant economic power of potential white members, which cannot yet be balanced by black political embeddedness. However, there exists a local ladies' business group with both black and white participants who meet regularly.

In one case, a local black entrepreneur received credit and business training from a South African company, and took over a retail grocery that belonged to it. The company is still involved in both wholesale and 
retail. He explained that he is given credit and business advice because the more he sells, the more he buys from them and the more they earn. This entrepreneur believes that the South African company is going to withdraw from retail, but this is not verified by a respondent in the company. ${ }^{16}$ The shop is situated in a locality with severe competition from other shops, and so the role as a mere supplier to the local black entrepreneur may be less risky and more economical to the South African company. Another local black entrepreneur has white business advisors and is claimed to be successful partly because he copies the business strategies of the chain stores. Black-white interaction at this level is the exception rather than the rule.

White entrepreneurs and managers of chain stores do not totally lack local social embeddedness. Some have lived in the North for several years, some plan to remain and there are examples of involvement in local development initiatives. However, their enterprises belong more to Windhoek and South Africa-based networks. Personal relations between black and white exist, but are not very common.

\section{PROSPECTS FOR MANUFACTURING}

Fourteen of the local black entrepreneurs in the sample were involved in some kind of manufacturing. The sewing sector produces wedding gowns, other clothing, linen and curtains. Some entrepreneurs make furniture and coffins. In the grocery sector one finds food processing such as sugar refining, mixing of vinegar and milling. Auto repairs are sometimes combined with welding, manufacture of steel car parts, and even ploughs. Production of bricks and tiles, and printing of cards and T-shirts also take place. Mostly the operations are small scale and cater to local niche markets with relatively simple products, and they are also often a side activity. Sales at the upper end of the market are the exception rather than the rule. Some manufacturers planned to expand production step by step, but there was little interest in initiating new manufacturing projects. They found it difficult to identify products that it would be economically feasible to manufacture in the North. Difficulties in getting bank loans and lack of information and training were also mentioned as constraints to manufacturing. Based on negative personal experiences, one local black entrepreneur suspected that good business ideas were stolen by consultants and potential partners, and initiated in the southern part of the country. ${ }^{17}$

The small size of the local market and imports from South Africa were also mentioned as constraints. South Africa is the main export market and Namibian product standards are still based on South African standards. One entrepreneur complained that it was difficult to fulfil 'the South 
African requirements'. In practice, the standards may require that a specific South African input is used. 'The government says that changes are in the pipeline - they are still in the pipeline after i years' (local black entrepreneur). Even at present the entrepreneur struggles to get an input he needs from South Africa in order to start his manufacturing project. To his mind, this shows that South African standards prevent manufacture of products in Namibia that compete with South African products. The Small Business Information Centre in Windhoek stresses that sourcing from South Africa is more than a matter of product standards. Quality, range and price competition are important reasons for sourcing (personal communication). As noted above, in the longer term the internet may foster purchases of inputs in other countries and so weaken the South African monopoly, which acts as a barrier to manufacturing. Although this implies some changes in the facilitative circuit of power, it is not sufficient to spur manufacturing on a large scale in Namibia. Competition from products made in South Africa will still be strong.

The strong structural barriers against manufacturing in the North, such as the size of the Namibian market and unequal competition with South Africa, explain why the power of domestic and foreign retailers whose networks are basically embedded in South Africa is strong. Moreover, the footing of powerful actors in the local retail economy who have their supply base in South Africa does not encourage local manufacturing on any scale. Nor does lack of trust in relations with business partners, banks and the local administration encourage this. The risk of failure is too great.

The limited manufacturing that takes place in the North at present is small and largely of the artisan and workshop type. The activities are important in terms of livelihood and provide employment, but due to the overall constraints they are unlikely to generate a process of sustained industrialisation in the foreseeable future.

PROSPECTS FOR ECONOMIC DEVELOPMENT

One local black entrepreneur observed that: 'development is coming in, but mostly from the outside. There is growth, but the income is going out again.' This puts the problem in a nutshell. A lot of the economic activity is induced from outside with the decentralisation policy and the influx of South African chain stores. This policy generates both permanent jobs in the civil service and temporary jobs in construction. However, only $16 \%$ of the economically active population in Oshana are employed in wholesale, retail and repair, and only $9 \%$ in public administration and defence (NDG n.d.). ${ }^{18}$ 
Almost all of the interviewees agreed that total economic activity and consumption in the North has increased since independence and particularly since the mid-rg9os. But despite the retail boom, it is doubtful whether this contributes a positive net effect to employment. The chain stores out-compete the local stores and employ fewer workers, although they pay their workers better than the local stores.

Unfortunately the general pattern is that increases in consumption imply increasing imports rather than local production. As already mentioned, the part of the value chain that is located in the study area is short, and networks are largely outward-oriented. There are no particular signs that the North is becoming important enough to foreign enterprises for them to reinvest and create new linkages in the local economy in order to obtain a solid footing. On the contrary, the direct link to South Africa has increased in importance, because tough price competition requires 'everybody' to have direct access to the suppliers. Not even the smaller local black entrepreneurs in sales and workshops need the local big entrepreneurs as middlemen to the same degree as before. Moreover, both local black entrepreneurs and entrepreneurs from outside are increasingly aware of the fact that the market is not big enough for all of the retailers.

Pendleton et al.'s (1993) study of socio-economic conditions of 520 households in the Oshakati-Ondangwa nexus showed that half of the adult population and half of the households in their survey were unemployed. The mean annual income was Rand 9,754, but variations in income were large. The mode was Rand 3,600 and the median was Rand $4,786 .{ }^{19}$ A survey carried out in Oshakati in 2000 found that $17 \%$ of the households had no income at all, and that one third of households earned less than NAD 725 a month, or NAD 8,700 annually. The average household size was 5.2 persons, and this income was less than that considered necessary to pay for services such as water and sanitation (Urban Dynamics 200I). ${ }^{20}$ Namibia Development Consultants (n.d.) hold that the average annual household income in Oshana is NAD I0,528, and that more than $40 \%$ of the households in the region are 'affected by poverty'. ${ }^{21}$ The average national income is NAD 17,189 . Although the figures are not directly comparable and should be treated with caution, they indicate that the prospects for sustained economic development in the North are still small. Conditions at present do not seem to contribute to a differentiated and well-proportioned local economy.

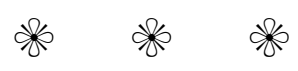


Local black entrepreneurs are more locally embedded than domestic and foreign capital, but the difference is less than expected. The value chains and networks of all three capitals are first and foremost directed towards South Africa. Local black entrepreneurs and some domestic entrepreneurs are however more prone to reinvest locally than South African chain stores. When out-competed in their main line of business, the problem is for local black entrepreneurs to identify alternative activities for viable and productive new investments.

The political elite has strong ties to the North, but the political embeddedness of local black entrepreneurs is also less than expected. Despite special measures to support local black entrepreneurs in the area of credit and access to government tenders, the outcome is relatively meagre. It is still difficult to obtain both, and the measures are not sufficient for most local black entrepreneurs to withstand the strong competition from large companies that the free trade policy opens up. Market-based incentives of the decentralisation policy also favour the stronger parties, who are mainly from southern Namibia or South Africa, where economic power rests with the white business elite.

Some aspects of cultural embeddedness, such as social obligations and conspicuous consumption to an extent that may undermine the business, have diminished. There is a gradual shift to more modern business practices. Local black entrepreneurs are concerned that their businesses should not die with them, and are shifting from the traditional system of inheritance to joint ventures and wills. The entrepreneurs do reinvest. It is impressive what has been achieved by small amounts of capital step by step over a number of years. The present problem is the vulnerability of these undertakings to competition from large and capital-strong actors from outside.

Common culture and political cooperation with the neighbouring countries, Angola and DRC, provide few significant alternative market outlets for local black entrepreneurs. However, they benefit some local black entrepreneurs in niche activities who have strong personal relations there. The problem is the extreme outward-oriented economy of Namibia and the lack of manufacturing. This makes it more attractive for the neighbouring countries to deal directly with producers in South Africa.

Social embeddedness is strikingly outward-oriented, because most suppliers are located in South Africa and Windhoek. There are signs that lack of trust reduces the scope of social embeddedness for local black entrepreneurs in the North. Moreover, black and white entrepreneurs and investors are mainly embedded in separate social networks. Increasing marginalisation of the local black entrepreneurs in competition may 
increase frustration and suspicion and thus accentuate the black-white divide.

In studies of local economic development, an analytical framework that combines value chains analysis and the notion of political, cultural and social embeddedness is useful. The notion of value chains describes the activities that are interlinked in the economic networks. This is important as some activities are more beneficial to economic development than others. The activities that presently dominate in the North, civil service, construction and trade, are unlikely to become vehicles of economic development. Tough price competition and low levels of income are incompatible with demand-induced economic development.

Social relations, as in political, cultural and social embeddedness, entail power relations that influence what activities are located where. The findings challenge the proposition that the more locally embedded an economic activity is, the more conducive it is to economic development. It is not sufficient to focus on the degree of local embeddedness, because some forms of local embeddedness, such as social obligations, may also impede economic development. However, in this case, the data suggest that expenditure on social obligations to the detriment of reinvestment in economic enterprises is diminishing in the North. To the extent that the tough competition from outside results in a withdrawal to farming, this also impedes local economic development. The magnitude of this phenomenon warrants further research. Having said all this, and as the nature of power relations reveal, it is not local cultural embeddedness as such, but the economic dominance and competition from South Africa, that is the main impediment to economic development in Northern Namibia. Local political embeddedness is shallow and political measures are not taken that significantly reduce the implications of this dominance.

\section{NOTES}

I. Information obtained in November 1998 in an interview at Chamber of Commerce and Industry and Small Scale Business Development, Northern Namibia Region.

2. Social development, on the other hand, is measured by such indicators as life expectancy, nutritional standards and educational standards, which reflect how people are affected by economic development, positively or negatively (Hesselberg I985). Social development lies beyond the scope of this project.

3. See Gereffi i996, Gereffi et al. 200I, and Sturgeon 200 I.

4. These are in turn manifestations of superstructure (the social, cultural, political and spatial organisation of society), which in turn can be explained by infrastructure (Johnston I997). Infrastructure refers to economic processes and the material base to society. Human agency may affect the structures.

5. The concept of cognitive embeddedness deals with the fact that rationality based on a full view of a situation is limited.

6. Here place refers to the fact that power relations in a location are shaped by place-specific conditions. Space refers to the fact that events in one place may affect power relationships in other places. 
7. Micro enterprises and enterprises in the informal sector were not included in this study. The larger of the small entrepreneurs use electricity, and the Electricity Board was willing to give us access to their lists. This was a good starting point for the identification of potential respondents. The telephone directory was less up-to-date, but we could possibly have obtained similar lists of entrepreneurs from the Town Council.

8. The bantustan policy was pursued in the period $1948-77$.

9. The exception is when rights over national resources are involved.

Io. NAD I =USD o.I2 (June 2003).

II. With South Africa, Swaziland, Lesotho and Botswana.

I2. The objective of the decentralisation policy is to decentralise power to enhance and guarantee participatory democracy and ensure rapid sustainable development.

I3. Although white males are still overrepresented in management positions and affirmative action did not put an end to their appointments and promotions, black males are its main beneficiaries (Jauch I998).

I4. Many respondents talked about a 'return' or withdrawal to farming as a new trend, but few of them were involved in this or had concrete plans to do so themselves. The idea of such a 'return' or withdrawal is interesting in its own right, because it tells something about the difficult economic conditions that black entrepreneurs face in the North. A quantitative study is needed to examine the extent of the phenomenon.

I5. In order for him to remain anonymous and to keep the business idea a secret, I had to promise not to mention what type of manufacturing.

I6. The respondent was a local employee who was told by the foreign management to answer our questions. She was very careful about what she said throughout the interview.

I7. This has not been further examined.

I8. The NDC population figures are based on the May 2000 projections of the Central Bureau of Statistics.

I9. As mentioned in the text above, Rand and NAD have been freely interchangeable since I993.

20. The income data are from a survey carried out by Urban Dynamics in April 2000 which underlies their Structure Plan of 200I. The year referred to is not explicitly mentioned, but is probably I999.

2I. The concept of poverty is not defined in the report.

\section{R E F E R E N C E S}

Clegg, S. R. I989. Frameworks of Power. London: Sage.

Curry, S. \& C. Stoneman. I993. 'Problems of industrial development and market integration in Namibia', Fournal of Southern African Studies I9, I : 40-59.

Dicken, P., F. Forsgren \& A. Malmberg. I994. 'The local embeddedness of transnational corporations', in A. Amin \& N. Thrift, eds., Globalization, Institutions and Regional Development in Europe. Oxford University Press, 23-46.

Endresen, S. B. \& H. Jauch. 2001. Export Processing Zones in Namibia: taking a closer look. Windhoek: Labour Resource and Research Institute (LaRRI).

Gereffi, G. I996. 'Commodity chains and regional divisions of labour in East Asia', Journal of Asian Business I2, I: $75^{-\mathrm{I} 12 .}$

Gereffi, G., J. Humphrey, R. Kaplinsky \& T. Sturgeon. 200I. 'Introduction: value chains and development', IDS Bulletin 32, 3: I-8.

Gipouloux, F. 2000. 'Networks and guanxi: towards an informal integration through common business practices in Greater China', in Chan Kwok Bun, ed., Chinese Business Networks. Singapore: Prentice Hall; Copenhagen: Nordic Institute of Asian Studies, 57-70.

Granovetter, M. I985. 'Economic action and social structure: the problem of embeddedness', American Fournal of Sociology 91 : 48I-510.

Granovetter, M. I992a. 'Economic action and social structure', in M. Granovetter \& R. Swedberg, eds., The Sociology of Economic Life. Boulder, CO: Westview, 53-8I.

Granovetter, M. I992b. 'Economic institutions as social constructions: a framework for analysis', Acta Sociologica 35: $3^{-\mathrm{II}}$.

Hesselberg, J. I985. The Third World in Transition: the case of the peasantry in Botswana. Uppsala: Scandinavian Institute of African Studies. 
Isaksen, A. I994. 'Regional næringsutvikling og framvekst av spesialiserte produksjonsområder'. Avdeling for samfunnsgeografi, Universitetet i Oslo: Dr. polit avhandling. Agderforsknings skriftserie nr. 5/94.

Jauch, H. 1998. Affirmative Action in Namibia: redressing the imbalances of the past? Windhoek: New Namibia Books.

Johnston, R. J. 1997. Geography and Geographers: Anglo-American geography since 1945. London: Arnold.

Kadhikwa, G., T. Kangueehi \& A. Erastus-Sacharia. 1996. 'Existing and potential entrepreneurs in Ondangwa, Oshakati, Swakopmund and Walvis Bay'. NEPRU Working Paper No. 6o. Windhoek: The Namibian Economic Policy Research Unit.

Kennedy, P. 1988. African Capitalism: the struggle for ascendancy. Cambridge University Press.

Labour Resource and Research Institute (LaRRI). 200I. Playing the Globalisation Game: the implications of economic liberalisation for Namibia. Windhoek: LaRRI.

Malan, J. S. 1995. Peoples of Namibia. Windhoek: Rhino Publishers.

Mbuende, K. I986. Namibia and the Broken Shield: anatomy of imperialism and revolution. Malmö: Liber.

Ministry of Trade and Industry (MTI). 1998. The Small Business Baseline Survey, vol. I. Windhoek: MTI.

MTI. 1999. Industrial Policy beyond 2000. Windhoek: MTI.

Namibia Development Consultants (NDC). Undated. Regional Development Plan 2001/2002-2005/2006. Oshana: Oshana Regional Council, Republic of Namibia.

Nicholas, S. M. 1994. 'The state and the development of African capitalism in Zimbabwe', in C. Leys \& B. J. Berman, eds., African Capitalists in African Development. Boulder, CO: Lynne Rienner, 95-II3.

Ostergaard, T. 1994. "The role of "national" bourgeoisie in national development: the case of the textile and clothing industries in Zimbabwe', in G. Leys \& B. J. Berman, eds., African Capitalists in African Development. Boulder, CO: Lynne Rienner, II5-37.

Pedersen, P. O. 200I. 'East African micro entreprises negotiating social space: an introduction', in P. O. Alila \& P. O. Pedersen, eds., Negotiating Social Space: East African micro enterprises. Trenton, NJ \& Asmara: Africa World Press, I-24.

Pedersen, P. O. \& D. McCormick. I999. 'African business systems in a globalising world', fournal of Modern African Studies 37, I: 109-35.

Pendleton, W., D. LeBeau \& C. Tapscott. I993. 'A socio-economic assessment of the Oshakati/ Ondangwa Nexus'. Windhoek: University of Namibia, Namibian Institute for Social and Economic Research, Research report io. Updated version February.

Reinert, E. \& V. Riiser. 1994. 'Recent trends in economic theory: implications for development geography', Oslo: STEP Report I2.

Republic of Namibia. 1997. Namibia: policy and programme on small business development. Windhoek: Government of the Republic of Namibia.

Seers, D. 1972. 'What are we trying to measure?', Journal of Development Studies 8, 3: I-13.

Senghaas, D. 1985 . The European Experience: a historical critique of development theory. Leamington: Berg.

Simon, D. 1985. 'Decolonisation and local government in Namibia: the neo-apartheid plan, 1977-83', Fournal of Modern African Studies 23, 3: 507-26.

Simon, D. 1996. 'Restructuring the local state in post-apartheid cities: Namibian experiences and lessons for South Africa', African Affairs 95, 378: $5^{\mathrm{I}-84}$.

Simon, D. 200I. 'Trading spaces: imaging and positioning the "new" South Africa within the regional and global economies', International Affairs 77, 2: 377-405.

Sparks, D. P. \& D. Green. 1992. Namibia: the nation after independence. Oxford: Westview.

Sturgeon, T. J. 200I. 'How do we define value chains and production networks?', IDS Bulletin 32, 3: $9^{-18 .}$

Swedberg, R. \& M. Granovetter. I992. 'Introduction', in M. Granovetter \& R. Swedberg, eds., The Sociology of Economic Life. Boulder, CO: Westview, I-26.

Taylor, M. 1994. 'The business enterprise, power and patterns of geographical industrialisation', in S. Conti, E. J. Malecki \& P. Oinas, eds., The Industrial Enterprise and its Environment: spatial perspectives. Aldershot: Avebury, 99-122.

Taylor, M., M. Bobe \& S. Leonard. 1995. 'The business enterprise, power networks and environmental change', in M. Taylor, ed., Environmental Change: industry and industrial policy. Aldershot: Avebury, 57-8I.

Traders. 200I. 'DRG: Africa's sleeping giant'. Issue 8, October 2001-February 2002: 17-8.

UNIDO. 1990. Namibia: industrial development at independence. Industrial development review series. Vienna: UNIDO.

UNIDO. 1994. Namibia: new avenues of industrial development. Industrial development review series. Vienna: UNIDO. 
UNIDO. n.d. 〈http://www.unido.org/geostat.cfm?cc=NAM 〉. Downloaded June 2003.

Urban Dynamics Town and Regional Planners. 200I. Oshakati Structure Plan 200I. Windhoek.

Wu, Wei-ping. 2000. 'Transaction cost, cultural values and Chinese business networks: an integrated approach', in Chan Kwok Bun, ed., Chinese Business Networks. Singapore: Prentice Hall; Copenhagen: Nordic Institute of Asian Studies, 35-56.

Zukin, S. \& P. DiMaggio. I99o. 'Introduction', in S. Zukin \& P. DiMaggio, eds., Structures of Capital: the social organization of the economy. Cambridge University Press, $\mathrm{I}-36$. 